DOI: https://doi.org/10.47405/mjssh.v6i8.952

\begin{tabular}{|c|c|}
\hline 4 & Malaysian Journal of Social Sciences and Humanities (MJSSH) \\
\hline $\begin{array}{l}\text { Malaysian Juoural of } \\
\text { Social ccciecces and }\end{array}$ & Volume 6, Issue 8, August 2021 \\
\hline (MJ-sSH) & e-ISSN : 2504-8562 \\
\hline & $\begin{array}{l}\text { Journal home page: } \\
\text { www.msocialsciences.com }\end{array}$ \\
\hline
\end{tabular}

\title{
Hubungan Antara Efikasi Kendiri Guru dengan Prestasi Kerja dalam kalangan Guru-Guru Kawasan Pedalaman, Sabah
}

\author{
Zulaine Bin Awang Taul ${ }^{1}$, Mohd Khairuddin Abdullah ${ }^{2}$, Mohd Mahadzir Rahimi Bin Mohamed Nawi ${ }^{3}$ \\ ${ }^{1}$ Kolej Vokasional Likas, Sabah \\ 2Universiti Malaysia Sabah (UMS) \\ 3MRSM Kota Putra Besut, Terengganu
}

Correspondence: Zulaine Bin Awang Taul (azat8569@gmail.com)

\begin{abstract}
Abstrak
Kajian ini bertujuan untuk mengkaji efikasi kendiri guru dan prestasi kerja dalam kalangan guru-guru di sekolah menengah kawasan pedalaman, Sabah. Kajian yang melibatkan seramai 375 orang responden yang dipilih menerusi persampelan bertujuan dan rawak mudah adalah terdiri daripada guruguru yang terlatih. Kajian ini berbentuk deskriptif statistik yang menggunakan soal selidik berkaitan dengan efikasi kendiri guru dan prestasi kerja. Kajian ini dianalisis dengan menggunakan Statistical Package for Social Science (SPSS). Statistik deskriptif seperti frekuensi, peratusan dan min serta sisihan piawai digunakan dalam kajian ini untuk melihat tahap kedua-dua pemboleh ubah. Selain itu, analisis korelasi pearson juga digunakan bagi menguji hipotesis kajian. Dapatan mendedahkan skor min bagi tahap keseluruhan efikasi kendiri guru dan prestasi kerja yang dikaji berada pada tahap yang tinggi. Di samping itu, kajian juga mendedahkan adanya hubungan positif yang signifikan antara efikasi kendiri guru dengan prestasi kerja. Keputusan ini secara langsungnya menolak hipotesis nol yang telah dibina.
\end{abstract}

Kata kunci: efikasi kendiri guru, prestasi kerja, kawasan pedalaman

\section{The Relationship Between Teachers' Self-Efficacy and Job Performance Among Teachers in Interior Areas, Sabah}

\begin{abstract}
This study aims to examine the self-efficacy of teachers and job performance among teachers in secondary school in interior areas, Sabah. The study involved a total of 375 respondents who were selected through purposeful and simple random sampling consisted of trained teachers. This study is a descriptive statistical study that uses a questionnaire related to teacher self -efficacy and job performance. This study was analyzed using the Statistical Package for Social Science (SPSS). Descriptive statistics such as frequency, percentage and mean as well as standard deviation were used in this study to look at the levels of both variables. In addition, pearson correlation analysis was also used to test the study hypotheses. The findings revealed that the mean score for the overall level of self -efficacy of teachers and the work performance studied was at a high level. In addition, the study also revealed a significant positive relationship between teachers' self -efficacy and job performance. These results directly reject the null hypothesis that has been constructed.
\end{abstract}


Keywords: teacher self -efficacy, job performance, interior areas

\section{Pengenalan}

Profesion keguruan kini telah memasuki era baharu. Peranan yang dimainkan oleh insan yang bergelar pendidik pada suatu ketika dahulu hanya sebagai penyampai ilmu kini berperanan sebagai pemudah cara pengetahuan. Para guru dituntut supaya lebih bersedia dan peka dalam melahirkan serta menggunakan beberapa situasi pembelajaran secara cekap dan efektif (Noriati, Boon \& Wong, 2010). Pendidikan yang berkesan mungkin tidak akan terjadi melainkan guru berada pada keadaan yang membolehkannya mengurus pendidikan dengan baik sehingga pelajar mampu mencapai manfaat secara maksimum (Ahmad, 2003). Oleh yang demikian seseorang guru mesti mempunyai kesungguhan dalam mendidik anak bangsa di samping mempunyai komitmen yang kukuh setelah mereka ditugaskan untuk menggalas tanggungjawab tersebut (Syed Kamarzuaman, Mohd Zaki \& Julismah, 2014). Ini kerana dalam persekitaran pembelajaran, guru berperanan sebagai pemudah cara pembelajaran, pemimpin pedagogi yang berinovatif, pencetus ke arah pemikiran pelajar serta pembimbing yang sentiasa berada di persekitaran untuk memandu pembelajaran pelajar (Syed Ismail \& Ahmad Subki, 2010).

Di samping itu, menurut Amin (2008) seseorang pendidik haruslah berupaya menguasai segala pengetahuan mahu pun kefahaman yang terkini dalam profesion mereka. Ini dilakukan supaya relevan dengan keadaan semasa yang efektif dan membolehkan pembelajaran dilakukan secara berkesan. Oleh yang sedemikian, adalah penting bahawa seseorang yang melibatkan diri dalam profesion ini mestilah sentiasa berusaha dalam mempertingkatkan kecekapan, kebolehan prestasi serta menunjukkan keterampilan masing-masing agar dapat bertanding pada era teknologi terkini (Noriati et at., 2010). Lantas, bagi menguruskan guru yang merupakan aset terpenting dalam bidang pendidikan ini, maka sudah pasti aspek prestasi kerja perlu diberikan perhatian yang lebih khusus. Ini kerana menurut Aziah, Loh dan Abdul Ghani (2015) guru yang terlibat dalam pendidikan merupakan penyumbang modal insan dan intelek kepada organisasi pendidikan.

Aspek prestasi kerja sering dikaitkan dengan pencapaian para pelajar di sekolah. Kajian-kajian lepas mendapati terdapat perkaitan yang positif antara prestasi kerja guru dengan pencapaian pelajar (Osagie \& Akinlosotu, 2017; Mamat, 2016; Lia Tresna \& A. Sobandi, 2017). Oleh yang sedemikian, pencapaian yang baik dari pelajar ini dapat ditingkatkan dengan menambah peningkatan kemampuan pengajaran guru serta prestasi kerja mereka. Ini kerana menurut Mamat (2016) kewujudan guru yang mempunyai kemampuan mengajar dan berprestasi tinggi memungkinkan untuk memberi nilai positif dalam mencapai tujuan yang diinginkan, iaitu peningkatan hasil pembelajaran pelajar yang memberi kesan positif terhadap peningkatan kualiti pendidikan di sekolah. Oleh yang demikian, dalam mengetahui tahap prestasi kerja dalam kalangan guru-guru di kawasan pedalaman, maka faktor-faktor yang berupaya untuk mempengaruhi prestasi kerja juga haruslah diterokai. Salah satu aspek yang mempunyai kaitan dengan prestasi kerja adalah efikasi kendiri (Norsimah \& Mohd Mahadzir, 2020; Achmad \& Nani, 2019; Fauzia, Farah, \& Nadia, 2012; Hanif, 2004). Kajian lepas juga telah mendedahkan bahawa efikasi kendiri guru adalah penting dalam memastikan kualiti sesebuah sekolah di samping mempunyai kepercayaan terhadap keupayaan diri untuk mengendalikan proses pembelajaran dan pengajaran yang berkesan (Tschannen-Moran \& Hoy, 1998; Iffahzuleha, 2014). Berdasarkan pernyataan ini maka pengkaji ingin mengenal pasti berkenaan tahap efikasi kendiri guru dan prestasi kerja dalam kalangan guru-guru di sekolah menengah kawasan pedalaman, Sabah di samping menentukan hubungan antara efikasi kendiri guru dengan prestasi kerja.

\section{Objektif Kajian}

Kajian ini bertujuan untuk menentukan tahap skor min efikasi kendiri guru di samping melihat hubungan efikasi kendiri guru dengan prestasi kerja guru-guru sekolah menengah di pedalaman Sabah. 
Berdasarkan tujuan kajian ini maka objektif kajian telah digariskan dalam kajian ini adalah seperti berikut:

i. Mengenal pasti tahap efikasi kendiri guru sekolah menengah di kawasan pedalaman, Sabah.

ii. Mengenal pasti tahap prestasi kerja dalam kalangan guru-guru sekolah menengah di kawasan pedalaman, Sabah.

iii. Mengenal pasti hubungan antara efikasi kendiri guru dengan prestasi kerja dalam kalangan guru-guru sekolah menengah di kawasan pedalaman, Sabah.

\section{Hipotesis Kajian}

Hipotesis nol kajian yang dibina dalam kajian ini adalah seperti berikut:

i. Tidak terdapat hubungan antara efikasi kendiri guru dengan prestasi kerja dalam kalangan guru-guru sekolah menengah di kawasan pedalaman, Sabah.

\section{Sorotan Literatur}

Secara umumnya efikasi kendiri guru dirujuk sebagai kepercayaan seseorang guru pada keupayaan diri mereka untuk melaksanakan pelbagai tugasan pengajaran bagi mencapai matlamat pengajaran secara khusus (Bandura, 1997; Woolfolk-Hoy, 2000). Efikasi juga dianggap elemen penting dalam diri seseorang guru kerana ianya terus merujuk kepada kebolehan diri untuk belajar, menjalankan tugasan serta ingin mendapatkan hasil yang dikehendaki (Bandura, 1986, 1977). Menurut Khalid (2009) konsep efikasi berkaitan dengan kekuatan aras kepercayaan individu yang mempengaruhi tingkah laku dan ianya berhubung dengan sesuatu keadaan yang mereka hadapi. Selaras dengan itu, Rahimah, Rosini, Abdullah dan Habsah (2014) menyatakan efikasi kendiri dirujuk sebagai persepsi kendiri atau jangkaan seseorang terhadap kecekapan yang akan dihasilkan mereka berbanding kecekapan sebenar yang dimiliki. Oleh itu, kajian Gibson dan Dembo (1984) menunjukkan bahawa guru yang berefikasi rendah kurang kesungguhan dalam memperbaiki kelemahan murid dan cenderung mengabaikan perkembangan kognitif dan keupayaan murid. Ini berbanding dengan guru yang berefikasi tinggi lebih menerapkan strategi pengalaman masteri berbanding guru yang rendah efikasi pengajarannya.

Berkaitan kajian tahap efikasi kendiri guru pula hasil kajian Norsimah dan Mohd Mahadzir (2020), Haidi (2019), Mohd Mahadzir (2017), Mohd Mahadzir, Khalid, Dewi Isma, Norsimah dan Zulaine (2014), Rahimah et al. (2014), Khalid (2009) dan Teng (2006) mendapati min tahap efikasi kendiri guru melebihi nilai 6.00 bagi guru-guru di sekolah menengah yang dikaji. Dapatan kajian ini juga mempunyai persamaan dengan dapatan Senemoglu dan Demirel (2009). Hasil kajian mereka mendapati kebanyakan guru sekolah rendah di Turkey mempunyai tahap efikasi yang tinggi. Hasil penyelidikan Andi (2007) juga mendapati guru-guru yang mengajar di sekolah menengah kebangsaan daerah Pontian Johor mempunyai tahap efikasi kendiri yang tinggi terhadap kepemimpinan pengajaran pengetua mereka. Di samping itu, dapatan kajian yang dilakukan oleh Khalid (2009) juga mendapati guru-guru keluaran Diploma Perguruan Malaysia (DPM) adalah lebih berkeyakinan tinggi dalam efikasi guru dan setiap dimensinya berbanding guru-guru lepasan Kursus Perguruan Lepasan Ijazah (KPLI), Diploma Perguruan Lepasan Ijazah (DPLI) dan Sarjana Muda Pendidikan (SMP). Begitu juga kajian yang dilaksanakan oleh Ling, Mohamad Nizam dan Zakiah (2019) terhadap guru tingkatan enam di Pantai Barat Sabah mendedahkan guru-guru yang mempunyai tahap efikasi yang tinggi akan juga mendatangkan kepuasan kerja dalam kalangan mereka. Suntikan motivasi dalam kalangan guru-guru dalam meneruskan usaha melaksanakan pengajaran dan tugasan berkaitan akan terus berkekalan jika berlakunya peningkatan dalam efikasi dan kepuasan kerja guru. Menurut Syed Kamarzuaman et al. (2014) keyakinan guru untuk mengajar dianggap penting kerana pengajaran akan menjadi kurang berkesan dan menyebabkan murid bosan jika orang yang diberi tanggungjawab kurang berkeyakinan. Oleh itu, menurut Rahimah et al. (2014) setiap sekolah amat memerlukan guru yang berefikasi kendiri tinggi memandangkan mereka ini lebih bersedia dalam meneroka pelbagai strategi pengajaran dan bermotivasi dalam mencapai objektif. 
Selain itu, guru yang mempunyai prestasi kerja yang baik penting ke arah negara maju di samping berkongsi menjayakan pendidikan yang berkualiti (Norsimah \& Mohd Mahadzir Rahimi, 2020). Prestasi kerja adalah suatu tindakan kerja yang dimainkan oleh majikan dalam memastikan segala aktiviti serta produktiviti seseorang pekerja selaras dengan matlamat organisasi (Noel, 2009). Manakala menurut Mohamad Zakaria (2005) prestasi kerja diertikan sebagai keupayaan seseorang pekerja dalam mencapai tahap produktiviti kerja sama ada dari aspek kuantiti mahu pun kualiti. Kajiankajian terdahulu mengkaji prestasi kerja dalam pelbagai bidang dan pelbagai pemboleh ubah seperti efikasi kendiri guru. Kajian Halimatussaediyah dan Nuraini (2015) terhadap pekerja di Yayasan Pembangunan Keluarga Darul Takzim mendapati seramai 43 orang kakitangan atau 69.4\% mempunyai tahap prestasi kerja yang tinggi berbanding hanya 19 orang kakitangan $(30.6 \%)$ mempunyai prestasi kerja yang sederhana. Tahap prestasi kerja yang diperoleh oleh mereka adalah dikaitkan dengan tahap kepuasan kerja. Manakala prestasi kerja guru seperti yang dinyatakan dalam kajian Muhammad Amin, Rahmat, Muhammad Ayaz dan Malik (2013) adalah dalam keadaan baik dan bertahap tinggi. Guru digambarkan mempunyai kemahiran mengajar yang baik kerana menggunakan kaedah pengajaran yang berbeza di kelas, mengajar mengikut kemampuan pelajar, melakukan persiapan sebelum kelas dan adil dalam membuat penilaian terhadap pelajar. Namun kajian Nadiah, Amizawati dan Siti Farahhani (2019) mendapati prestasi kerja 378 orang guru sekolah kerajaan di Malaysia guru yang dikaji mempunyai nilai purata 3.33 yang membawa maksud secara puratanya prestasi kerja guru-guru berada pada tahap yang sederhana.

Manakala kajian efikasi kendiri guru dengan prestasi kerja juga telah dilakukan oleh para pengkaji terdahulu. Berdasarkan hasil kajian Rohman (2020), efikasi kendiri berpengaruh secara positif terhadap prestasi guru. Ini bererti efikasi kendiri mempunyai kaitan secara langsung dengan prestasi dalam kalangan guru yang dikaji di SMAN Wilayah II Jakarta Pusat. Kajian menyarankan supaya guru memiliki kepercayaan dan keyakinan diri terhadap kemampuan yang dimilikinya. Ini terutama dalam melaksanakan segala tugasan pembelajaran dan sentiasa berani serta tidak mudah patah semangat apabila berhadapan dengan masalah. Dapatan kajian Aslamiyah, Lahmuddin dan Effendy (2020) juga mendapati efikasi kendiri mempunyai kaitan dengan prestasi para guru yang dikaji. Individu yang mempunyai efikasi kendiri yang tinggi memandang tugas yang sukar sebagai cabaran bagi mereka yang seharusnya dihadapi dan bukannya sebagai ancaman yang harus dielakkan. Kajian yang dilakukan oleh Norsimah dan Mohd Mahadzir (2020) terhadap guru-guru yang mengajar di MRSM pula mendapati tahap prestasi kerja dalam kalangan guru berada pada aras yang tingi. Prestasi kerja hendaklah ditingkatkan secara berterusan memandangkan ianya penentu utama kepada keupayaan guru untuk mencapai matlamat yang telah ditetapkan. Di samping itu, kajian juga mendedahkan terdapatnya hubungan positif yang kuat antara efikasi kendiri guru dengan prestasi kerja guru.

Manakala kajian yang dilakukan oleh Song, Chai, Kim dan Bae (2018) terhadap prestasi kerja di Korea mendedahkan adanya perkaitan efikasi kendiri guru dengan prestasi kerja. Efikasi kendiri guru juga memberi kesan positif terhadap penglibatan kerja dan prestasi kerja mereka di samping hubungan antara penglibatan kerja dengan prestasi kerja adalah signifikan secara statistik. Ini seterusnya dapat menunjukkan betapa pentingnya hubungan interaktif antara faktor organisasi, persekitaran dan komponen tingkah laku individu untuk meningkatkan prestasi. Hasil kajian efikasi kendiri guru dan prestasi kerja guru di Rawalpindi dan Islamabad oleh Fauziah, Farah dan Nadia (2012) juga menunjukkan terdapatnya hubungan yang positif antara efikasi kendiri guru dengan prestasi kerja mereka. Hasil kajian juga mendedahkan bahawa guru wanita sekolah menengah mempunyai efikasi kendiri yang lebih tinggi berbanding guru lelaki. Guru dengan lebih banyak pengalaman kerja dan berkelayakan yang lebih tinggi mempunyai efikasi kendiri yang juga lebih tinggi. Hipotesis lain dari kajian ini ialah guru yang berpendidikan tinggi mempunyai efikasi kendiri yang lebih tinggi serta prestasi kerja yang lebih baik.

\section{Metod Kajian}

Dalam kajian ini, kaedah penyelidikan berbentuk kuantitatif dan pengumpulan maklumat adalah daripada sampel. Borang soal selidik telah digunakan untuk mengkaji tahap efikasi kendiri guru dan 
prestasi kerja dalam kalangan guru. Penyelidikan kuantitatif memerlukan sampel yang besar untuk dapatan yang lebih bermakna. Hasilan daripada analisis statistik ini selalunya dijadikan inferensi yakni digeneralisasikan kepada populasi (Chua, 2006). Kajian ini juga merupakan kajian deskriptif berbentuk tinjauan. Menurut Mohd. Majid (2000), penyelidikan deskriptif merupakan penyelidikan yang bermatlamat untuk menerangkan sesuatu fenomena yang sedang berlaku. Manakala kaedah tinjauan pula merupakan salah satu cara yang spesifik bagi mengumpul maklumat berkenaan sekumpulan populasi (Blake \& Champion, 1976). Pendekatan kaedah tinjauan dipilih kerana ianya satu kaedah yang popular. Di samping itu kaedah ini digunakan dalam mendapatkan data dari sampel saiz yang besar kerana proses menggunakan kaedah lain sukar dan kompleks (Mohd. Najib, 2003).

Populasi kajian hanya terdiri daripada guru-guru yang mengajar dan merangkumi 19 buah sekolah menengah kebangsaan yang dikategorikan di kawasan pedalaman, Sabah sahaja. Persampelan merupakan strategi penyelidikan di mana penyelidik boleh mendapatkan maklumat mengenai sesuatu populasi daripada sebilangan individu yang menganggotai populasi tersebut (Mohd. Majid, 2000). Pemilihan sampel dalam kajian ini adalah berdasarkan persampelan bertujuan dan rawak mudah. Persampelan bertujuan ini merujuk kepada prosedur persampelan sekumpulan subjek yang dipilih yang mempunyai ciri-ciri tertentu dipilih sebagai responden kajian (Chua, 2006). Sampel kajian yang diperoleh untuk kajian ini adalah seramai 375 orang guru daripada populasi guru. Sampel yang diperoleh ini selaras dengan jadual penentuan saiz sampel Krejcie dan Morgan (1970).

Bagi memperoleh data, alat utama yang digunakan adalah soal selidik. Menurut Mohd. Majid (2000) borang soal selidik ini sesuai digunakan memandangkan tujuannya untuk mendapatkan maklumat terutamanya dengan menggunakan sampel yang besar. Menurut Mohamad Najib (1999) pula instrumen berbentuk soal selidik mudah ditadbir setelah dibina dengan baik dan data senang diproses untuk dianalisis. Penggunaan soal selidik sebagai instrumen kajian juga popular digunakan dalam kalangan penyelidik memandangkan penggunaannya yang lebih praktikal dan berkesan (Mohd. Majid, 2000).

Instrumen kajian berbentuk soal selidik ini merangkumi soal selidik berkaitan efikasi kendiri guru iaitu Teacher Sense of Efficacy Scale (TSES) dan soal selidik prestasi kerja. Soal selidik efikasi kendiri guru dibangunkan oleh Tschannen-Moran dan Woolfolk-Hoy (2001) yang terdiri daripada penglibatan murid, strategi pengajaran dan pengurusan kelas. Soal selidik ini telah diterjemahkan ke dalam bahasa Melayu oleh Khalid (2009) dan menggunakan skala sembilan poin. Manakala soal selidik prestasi kerja yang digunakan adalah yang dibentuk oleh Strauss dan Sayles (1981) yang diadaptasi dan diubahsuai dalam kajian Mohamad Zakaria (2005) dan menggunakan skala lima poin. Data dianalisis dengan menggunakan frekuensi, min, peratus dan sisihan piawai di samping teknik statistik inferensi seperti korelasi pearson untuk menguji hipotesis kajian. Selain itu, bagi mengetahui kekuatan tahap min yang akan diperoleh, ianya dikategorikan mengikut tiga tahap (Yusof, 2007; Jamil, 2002; Landell, 1997) iaitu tahap rendah (1.00 -2.33), tahap sederhana (2.34 - 3.66) dan tahap tinggi (3.67 - 5.00). Manakala kekuatan korelasi antara dua pemboleh ubah yang terlibat akan diukur menerusi indeks pekali korelasi daripada Borg dan Gall (1983) iaitu 0.01 hingga 0.09 (boleh diabaikan), 0.10 hingga 0.29 (rendah), 0.30 hingga 0.49 (sederhana), 0.50 hingga 0.69 (kuat) dan 0.70 atau lebih (sangat kuat).

\section{Dapatan Kajian}

\section{Analisis Skor Min Efikasi Kendiri Guru}

Jadual 1 menunjukkan tahap min efikasi kendiri guru. Tahap efikasi kendiri guru pada keseluruhannya ialah 7.04 dan SD 0.85. Tahap efikasi kendiri guru mengikut dimensi pula mendapati dimensi penglibatan murid adalah $(\min =6.92, \mathrm{SD}=0.96)$, strategi pengajaran $(\min =7.00, \mathrm{SD}=0.88)$ dan pengurusan kelas $(\mathrm{min}=7.21, \mathrm{SD}=0.95)$. Skor min efikasi kendiri guru yang diperoleh pada keseluruhan dan mengikut dimensi adalah berada pada tahap yang tinggi. Dimensi pengurusan kelas adalah tahap tertinggi diikuti oleh dimensi strategi pengajaran dan penglibatan murid. 
DOI: https://doi.org/10.47405/mjssh.v6i8.952

Jadual 1: Analisis Skor Min Keseluruhan Efikasi Kendiri Guru dan Mengikut Dimensi

\begin{tabular}{lcc}
\hline \multicolumn{1}{c}{ Efikasi Kendiri Guru } & \multicolumn{2}{c}{ Min Sisihan Piawai (SD) } \\
\hline Penglibatan Murid & 6.92 & 0.96 \\
Strategi Pengajaran & 7.00 & 0.88 \\
Pengurusan Kelas & 7.21 & 0.95 \\
Keseluruhan & 7.04 & 0.85 \\
\hline
\end{tabular}

\section{Analisis Skor Min Prestasi Kerja}

Jadual 2 menunjukkan tahap skor min prestasi kerja dalam kalangan guru. Tahap prestasi kerja pada keseluruhannya ialah 3.86 dan SD 0.34. Tahap prestasi kerja mengikut dimensinya pula mendapati dimensi pengetahuan tentang kerja adalah $(\min =3.83, \mathrm{SD}=0.52)$, sikap $(\min =3.96, \mathrm{SD}=0.43)$, membuat pertimbangan $(\min =3.82, \mathrm{SD}=0.48)$, delegasi $(\min =3.97, \mathrm{SD}=0.48)$, kecekapan peribadi $(\min =3.78$, $\mathrm{SD}=0.49)$, kebolehan merancang $(\min =3.60, \mathrm{SD}=0.49)$, kepimpinan $(\min =3.98, \mathrm{SD}=0.50)$. Skor $\min$ prestasi kerja yang diperoleh pada keseluruhan berada pada tahap yang tinggi. Begitu juga dengan skor min mengikut dimensi prestasi kerja masing-masing berada pada tahap yang tinggi dan juga sederhana.

Jadual 2: Analisis Skor Min Keseluruhan Prestasi Kerja dan Mengikut Dimensi

\begin{tabular}{llll}
\hline \multicolumn{1}{c}{ Prestasi Kerja } & Min Sisihan Piawai (SD) & \\
\hline Pengetahuan Tentang Kerja & 3.83 & 0.52 \\
Sikap & 3.96 & 0.43 \\
Membuat Pertimbangan & 3.82 & 0.48 \\
Delegasi & 3.97 & 0.48 & \\
Kecekapan Peribadi & 3.78 & 0.49 \\
Kebolehan Merancang & 3.60 & 0.49 \\
Kepimpinan & 3.98 & 0.50 \\
Keseluruhan Prestasi Kerja & 3.86 & 0.34 \\
\hline
\end{tabular}

\section{Hubungan Efikasi Kendiri Guru dengan Prestasi Kerja}

Analisis Korelasi Pearson (r) telah dijalankan untuk menentukan sama ada terdapatnya hubungan antara efikasi kendiri guru dengan prestasi kerja dan setiap dimensinya. Analisis ini dilaksanakan untuk menjawab hipotesis nol yang telah dibina. Jadual 3 di bawah menunjukkan hasil kajian mendapati adanya hubungan yang signifikan dan berarah positif antara efikasi kendiri guru dengan prestasi kerja iaitu pada aras $\mathrm{p}<.05(\mathrm{r}=.540)$. Aras hubungan ini mendedahkan secara keseluruhannya berada pada tahap yang kuat dan berarah positif. Ini menggambarkan bahawa prestasi kerja para guru yang dikaji akan meningkat sejurus berlakunya peningkatan dalam efikasi kendiri guru. Begitu juga dengan ketiga-tiga dimensi efikasi kendiri guru mempunyai hubungan yang juga signifikan dengan prestasi kerja.

Jadual 3: Analisis Korelasi antara Efikasi Kendiri Guru dan Dimensinya dengan Prestasi Kerja dan Dimensinya

\begin{tabular}{ccc}
\hline & & Prestasi kerja \\
\hline Efikasi kendiri guru & Pearson Correlation & .540 \\
& Sig. (2-tailed) & .000 \\
Penglibatan murid & Pearson Correlation & .506 \\
& Sig. (2-tailed) & .000 \\
Strategi pengajaran & Pearson Correlation & .493 \\
& Sig. (2-tailed) & .000 \\
Pengurusan kelas & Pearson Correlation & .480 \\
& Sig. (2-tailed) & .000 \\
\hline
\end{tabular}




\section{Perbincangan Kajian}

Kajian yang dilaksanakan ini adalah berdasarkan satu keyakinan bahawa untuk menjadikan para tenaga pengajar terutamanya guru-guru yang melaksanakan proses pengajaran dan pembelajaran yang berjaya dan perlu mempunyai pengajaran yang baik dan guru yang mempunyai efikasi kendiri tinggi. Ini kerana guru yang mempunyai efikasi kendiri tinggi akan menerapkan strategi pengalaman masteri berbanding guru yang rendah efikasi pengajarannya cenderung mengabaikan perkembangan kognitif dan keupayaan murid (Gibson \& Dembo, 1984).

Hasil dapatan kajian bagi efikasi kendiri guru dalam kalangan guru-guru di kawasan pedalaman ini secara keseluruhannya menunjukkan tahap min efikasi kendiri guru yang tinggi. Tahap efikasi kendiri yang tinggi ini mencerminkan kecenderungan positif di kalangan responden terhadap keyakinan dan kemampuan mereka dalam melaksanakan tugasan pengajaran serta berupaya menghadapi cabaran dengan tabah. Begitu juga dalam ketiga-tiga dimensi efikasi kendiri yang merangkumi penglibatan murid, strategi pengajaran dan pengurusan kelas yang menunjukkan skor min guru yang mengajar juga adalah tinggi. Persepsi guru terhadap keberkesanan pengajaran mereka merangkumi keseluruhan kepercayaan mengenai kemampuan mereka sendiri untuk mengajar dan memberi kesan positif terhadap pembelajaran pelajar. Kepercayaan ini dihubungkan dengan corak tingkah laku yang ditunjukkan oleh guru di dalam kelas (Achurra \& Villardon, 2012). Dapatan kajian yang tinggi ini juga menggambarkan efikasi kendiri adalah penting dalam mempertingkatkan motivasi dan produktiviti para guru. Ini kerana Masturah dan Khalip (2018) menyatakan para guru akan mampu memberikan persediaan yang terbaik dalam proses pengajaran serta menyediakan kesediaan kepimpinan guru apabila mereka berefikasi tinggi. Namun walau pun dapatan ini bertahap tinggi, usaha yang berterusan perlu dilaksanakan supaya efikasi kendiri guru sentiasa berada pada tahap yang cemerlang. Hasil kajian ini selari dengan dapatan kajian tempatan terdahulu seperti Haidi (2019), Mohd Mahadzir Rahimi (2017), Mohd Mahadzir et al. (2014), Iffahzuleha (2014), Khalid et al. (2009) dan Teng (2006) yang memperoleh min efikasi kendiri yang melebihi nilai 6.00 bagi guru sekolah menengah yang mereka kaji.

Dapatan kajian ini juga mempunyai persamaan dengan dapatan Senemoglu dan Demirel (2009). Hasil kajian mereka mendapati kebanyakan guru sekolah rendah di Turkey mempunyai tahap efikasi yang tinggi. Ini bermakna guru ini mempunyai kepercayaan yang kuat dalam kemahirannya mengajar supaya pengajaran dan pembelajaran yang berkesan diperoleh. Hasil penyelidikan Andi Audryanah (2007) mendapati guru-guru yang mengajar di sekolah menengah kebangsaan daerah Pontian Johor mempunyai tahap efikasi kendiri yang tinggi terhadap kepemimpinan pengajaran pengetua mereka. Efikasi kendiri dalam konteks ini merujuk kepada persepsi kendiri atau jangkaan seseorang terhadap kecekapan yang akan dihasilkan berbanding kecekapan sebenar yang dimilikinya. Menurut Pajaras (2001) dalam Rahimah et al. (2014), individu yang mempunyai jangkaan efikasi kendiri yang tinggi ini akan lebih berusaha, bermotivasi dan cenderung untuk mencapai tahap prestasi yang lebih tinggi. Di samping itu, pendidik yang mempunyai efikasi kendiri yang tinggi pula akan mempamerkan sikap keterbukaan, mempunyai komunikasi yang baik serta mempunyai keinginan bekerjasama yang baik (Zuhaili \& Ramlee, 2017). Menurut kajian Ling et al. (2019) pula guru-guru yang mempunyai tahap efikasi yang tinggi juga akan mendatangkan kepuasan kerja dalam kalangan mereka dan seterusnya termotivasi untuk melakukan tugasan. Oleh yang demikian, demi memastikan tercapainya kecemerlangan sekolah, tingkah laku dan tugas mengajar hendaklah dilaksanakan dengan efektif. Ini hanya berlaku jika seseorang guru itu mempunyai keyakinan dan aras efikasi kendiri yang tinggi (Shafinaz, Chua, Hussein, Leong \& Shahrin, 2017).

Dapatan kajian juga mendedahkan tahap prestasi kerja pada keseluruhannya berada pada tahap yang tinggi. Menurut Mamat (2016) kewujudan guru yang mempunyai kemampuan mengajar dan berprestasi tinggi memungkinkan mereka untuk memberi nilai positif dalam mencapai tujuan yang diinginkan. Dapatan kajian ini selari dengan dapatan dalam pelbagai bidang seperti Halimatussaediyah dan Nuraini (2015) yang mendapati kaki tangan yang dikaji lebih ramai memperoleh aras prestasi kerja yang tinggi jika dibandingkan dengan mereka yang bertahap sederhana. Selain itu, guru yang digambarkan berkemahiran mengajar dengan baik serta menggunakan kaedah pengajaran yang 
berbeza di kelas juga merupakan mereka yang mempunyai tahap prestasi kerja yang baik (Muhammad Amin at el., 2013). Menurut mereka lagi, kemampuan mereka mengajar mengikut kemampuan pelajar serta adil dalam membuat penilaian terhadap pelajar juga menggambarkan mereka yang mempunyai prestasi kerja yang tinggi. Namun dapatan kajian ini bertentangan dengan kajian yang dilaksanakan oleh Nadiah et al. (2019) yang hanya mendapati prestasi kerja guru sekolah kerajaan di Malaysia yang dikaji berada pada tahap yang sederhana.

Ujian korelasi pearson telah digunakan untuk menganalisis sama ada terdapat hubungan efikasi kendiri guru dengan prestasi kerja dalam kalangan guru sekolah menengah di pedalaman. Hasil analisis korelasi tersebut menunjukkan adanya hubungan yang positif dan signifikan antara efikasi kendiri guru dengan prestasi kerja. Dapatan kajian ini menggambarkan prestasi kerja para guru yang dikaji akan berlaku peningkatan apabila adanya peningkatan dalam efikasi kediri guru. Dapatan kajian ini telah menyokong hasil kajian terdahulu seperti Rohman (2020), Aslamiyah et al. (2020) dan Norsimah dan Mohd Mahadzir (2020). Berdasarkan hasil kajian Rohman (2020) efikasi kendiri berpengaruh langsung secara positif terhadap prestasi guru. Ini bererti efikasi kendiri mempunyai kaitan secara langsung dengan prestasi dalam kalangan guru yang dikaji. Kajian menyarankan supaya guru memiliki kepercayaan dan keyakinan diri terhadap kemampuan terutama dalam melaksanakan segala tugasan pembelajaran. Dapatan kajian Aslamiyah et al. (2020) juga mendapati efikasi kendiri mempunyai kaitan dengan prestasi para guru yang mereka kaji. Mereka yang mempunyai efikasi kendiri yang tinggi akan memandang tugas sebagai cabaran walau pun dalam keadaan sukar.

Kajian ini juga selari dengan dapatan yang diperoleh dalam kajian Norsimah dan Mohd Mahadzir (2020) terhadap guru-guru yang mengajar di MRSM yang mendedahkan terdapatnya hubungan positif yang kuat antara efikasi kendiri guru dengan prestasi kerja. Menurut mereka, prestasi kerja hendaklah ditingkatkan secara berterusan kerana ianya penentu utama kepada keupayaan guru untuk mencapai matlamat yang telah ditetapkan. Selain itu kajian ini juga selari dengan kajian Song et al. (2018) terhadap prestasi kerja dan mendedahkan adanya perkaitan efikasi kendiri guru dengan prestasi kerja. Dapatan mereka juga mendedahkan efikasi kendiri guru memberi kesan positif terhadap penglibatan kerja dan prestasi kerja mereka di samping hubungan antara penglibatan kerja dengan prestasi kerja adalah signifikan secara statistik. Hasil kajian efikasi kendiri guru dan prestasi kerja guru di Rawalpindi dan Islamabad oleh Fauziah et al. (2012) juga selari dengan kajian ini. Kajian mereka menunjukkan adanya perkaitan yang positif antara efikasi kendiri guru dengan prestasi kerja guru yang mereka kaji. Hasil kajian juga mendedahkan bahawa guru wanita mempunyai efikasi kendiri yang lebih tinggi daripada guru lelaki. Begitu juga dengan guru yang lebih banyak pengalaman kerja dan berkelayakan yang lebih tinggi mempunyai efikasi kendiri yang lebih tinggi. Manakala kajian Demir (2020) menunjukkan bahawa efikasi kendiri adalah peramal terhadap tahap penglibatan pekerjaan guru melalui kesan sebahagian dari kepuasan kerja, komitmen organisasi, dan motivasi. Guru yang mempunyai persepsi tentang efikasi kendiri akan merasa puas dengan pekerjaan mereka sambil menguruskan tugas yang diberikan dengan berkesan untuk organisasi mereka. Pentadbir sekolah disaran untuk meningkatkan kepercayaan efikasi kendiri guru supaya menimbulkan sikap positif yang seterusnya dapat meningkatkan prestasi guru.

\section{Kesimpulan}

Keputusan kajian ini menunjukkan bahawa efikasi kendiri guru dan prestasi kerja menampakkan tahap amalan yang tinggi dalam kalangan guru-guru yang dikaji. Oleh yang demikian, guru di sekolah perlu mendapat sokongan daripada semua pihak supaya efikasi kendiri guru dan prestasi kerja yang tinggi dapat diperoleh dan dikekalkan. Ini juga secara tidak langsung boleh mempengaruhi pembelajaran pelajar. Amalan pengajaran yang merupakan tanggungjawab bersama seharusnya dikongsi bersama bagi mewujudkan perubahan yang positif terhadap pengajaran dan pembelajaran pelajar dalam bilik darjah. Lantaran itu, para guru dan pihak pentadbir sekolah haruslah menyedari bahawa pengajaran guru yang berkesan amat perlu dilaksanakan di sekolah. Oleh itu, efikasi kendiri guru serta prestasi kerja yang tinggi harus dicapai dan dikekalkan memandangkan kedua-duanya mempunyai pengaruh yang besar kepada keberkesanan sekolah. 


\section{Rujukan}

Achurra, C., \& Villardón, L. (2012). Teacher Self-Efficacy And Student Learning. The European Journal of Social \& Behavioural Sciences, 2(2), 366-383.

Ahmad Kilani Mohamed. (2003). Pengurusan Pendidikan di Sekolah: Huraian Menurut Perspektif Islam. University Teknologi Malaysia. Skudai.

Allinder, R.M. (1995). An Examination of the Relationship between Teacher Efficacy and Curiculum Based Measurement. Remedial \& Special Education, (16), 247-255.

Amin Senin (2008). Pembangunan Profesional Guru. Kuala Lumpur: Utusan Publications.

Andi Audryanah Mohd Noor. (2007). Kepimpinan Pengajaran dan Efikasi Kendiri Pengetua Sekolah Menengah dan Hubungannya dengan Pencapaian Akedemik Sekolah. Tesis Sarjana. Universiti Teknologi Malaysia.

Aslamiyah, S. Lahmuddin. \& Effendy, S. (2020). Pengaruh Efikasi Diri dan Motivasi Kerja Terhadap Kinerja Guru Sekolah Taman Kanak Kanak Di Kecamatan Medan Area, Tabularasa: Jurnal Ilmiah Magister Psikologi, 2(2) 2020: 143-152.

Aziah Ismail, Loh Hooi Yen \& Abdul Ghani Kanesan Abdullah. (2017). Komuniti Pembelajaran Profesional dan Efikasi Kendiri Guru Sekolah Menengah di Pulau Pinang. JuPiDi: Jurnal Kepimpinan Pendidikan, 2(1), 1-12.

Bandura, A. (1997). Self-Efficacy: The Exercise of Control. New York: W.H. Freeman.

Bandura, A. (1977). Self-Efficacy: Toward A Unifying Theory of Behavioral Change. Psychological Review, 84, 191-215.

Bandura, A. (1986). Social Foundations of Thouhgt And Action: A Social Cognitive Theory. New Jersey: Prentice Hall, Inc.

Blake, J. A. \& Champion, D. J. (1976). Method and Issues in Social Research. New York: John Willey and Sons.

Borg, W.R. \& Gall, M.D. 1983. Educational Research: An Introduction, Fifth Edition. New York: Longman.

Chua Yan Piaw. (2006). Asas Statistik Penyelidikan Buku 2. Kuala Lumpur: Mc Graw Hill Education.

Demir, S. (2020). The Role of Self-Efficacy In Job Satisfaction, Organizational Commitment, Motivation and Job Involvement. Eurasian Journal of Educational Research, 85, 205-224.

Fauzia, K., Farah, N.Q \& Nadia, A. (2012). The Relationship Between Teachers' Self Efficacy and Their Perceived Job Perormance. Interdisciplinary Journal of Contemporary Research in Business, 3(10).

Gibson, S. \& Dembo, M. (1984). Teacher Efficacy: A Construct Validation. Journal of Educational Psychology, 76(4), 569-582.

Haidi Bin Entoh. (2019). Pengaruh Pengalaman, Kesedaran Metakognisi dan Iklim Organisasi Sekolah terhadap Efikasi dalam Kalangan Guru-Guru Sekolah Rendah di dalam Zon Banggi, Kudat. Tesis Doktor Falsafah: Universiti Malaysia Sabah.

Halimatussaediyah Tamri \& Noraini Abdol Raop. (2015). Kepuasan Kerja: Hubungannya dengan Prestasi Kerja dalam Kalangan Kakitangan Yayasan Pembangunan Keluarga Darul Takzim (Ypkdt), Nusajaya, Johor Bahru (Job Satisfaction: The Correlation With Job Performance Among Staffs in Ypkdt, Nusajaya, Johor Bahru). Journal Of Human Capital Development (Jhcd), 8(2), 114-129.

Hanif, R. (2004). Teacher stress, Job performance and Self-Efficacy of Women School teachers. A Dissertation submitted to National Institute of Psychology, Quaid-i-Azam University, Islamabad.

Iffahzuleha Elmandily Binti Awaluddin. (2014). Hubungan antara efikasi guru dengan metakognisi dalam kalangan guru-guru sekolah rendah Pedalaman Satu di Sabah. International Conference on Education 2014 Sabah, Malaysia Official Conference Proceedings.

Jamil Ahmad. 2002. Pemupukan Budaya Penyelidikan di Kalangan Guru Sekolah: Satu Penilaian. Tesis Doktor Falsafah: Universiti Kebangsaan Malaysia.

Khalid Johori. (2009). Pola Efikasi Guru-Guru Novis Sekolah Menengah. Malaysian Journal of Learning and Instruction. Volume 6: 141-151.

Khalid Johari, Zurida Ismail, Shuki Osman \& Ahmad Tajudin Othman. (2009). Pengaruh Jenis Latihan Guru dan Pengalaman Mengajar Terhadap Efikasi Guru Sekolah Menengah. Jurnal pendidikan Malaysia, 34(2), 3-14. 
Krejcie, R., \& Morgan, D. (1970). Determining Sample Size for Research Activities. Educational and Psychological Measurement, 30, 607-610.

Landell K. 1997. "Management by Menu." London: Wiley and Sons Inc.

Lia Tresna, Y. \& Sobandi, A. (2017). Kinerja Mengajar Guru Sebagai Faktor Determinan Prestasi Belajar Siswa. Jurnal Pendidikan Manajemen Perkantoran, 2(2), 157-165.

Ling Lin, Mohamad Nizam Bin Nazarudin \& Zakiah Binti Noordin. (2019). Kepuasan Kerja dan Efikasi Guru Tingkatan Enam di Pantai Barat Sabah. International Journal of Education, Psychology and Counseling, 4(32), 51-66.

Mamat Rahmatullah. (2016). Kemampuan Mengajar Guru dalam Meningkatkan Kinerja Guru dan Hasil Belajar Siswa. TANZHIM Jurnal Penelitian Manajemen Pendidikan, 1(2), 119-126.

Masturah Zainal Abidina, Khalip Musa. (2018). Pengaruh Efikasi Kendiri Guru Pra Perkhidmatan terhadap Kesediaan Kepimpinan Guru. Management Research Journal, 8(1), 117-125.

Mohamad Zakaria Bin Mat Khazani. (2005). Hubungan antara Iklim Organisasi dan Prestasi Kerja di kalangan Guru Matematik Sekolah Rendah di Semenanjung Malaysia. Tesis Doktor Falsafah: Universiti Malaya.

Mohd Mahadzir Rahimi Mohamed Nawi. (2017). Iklim Sekolah, Efikasi Kendiri dan Prestasi Kerja Guru di Sekolah Berprestasi Tinggi Malaysia - Kajian Ke Atas MRSM. Tesis Doktor Falsafah: Universiti Malaysia Sabah.

Mohd Mahadzir Rahimi Mohamed Nawi, Khalid Johari, Dewi Isma Madzlan, Norsima Dasan \& Zulaine Awang Taul. (2014). Perbandingan Efikasi guru di Maktab Rendah Sains Mara (MRSM) Sabah dan MRSM Terengganu. International Conference on Education 2014 (ICEdu14) "Empowering Educator, Educational Honoring Teaching Profession". Pada 4-6 Jun 2014, Fakulti Psikologi dan Pendidikan, Universiti Malaysia Sabah.

Mohd. Majid Konting. (2000). Kaedah Penyelidikan Pendidikan. Kuala Lumpur: Dewan Bahasa Dan Pustaka.

Mohd. Khairuddin Abdullah @ Jerry. (2010). Hubungan antara Kepemimpinan Pengajaran, Efikasi Pengajaran dan Sikap Guru Kelas Intervensi Awal Membaca dan Menulis (Kia2m) Sekolah Rendah Di Sabah. Tesis Doktor Falsafah. Universiti Malaysia Sabah.

Mohamad Najib Abdul Ghafar. (1999). Penyelidikan Pendidikan. Skudai: Universiti Teknologi Malaysia.

Mohd. Najib Abdul Ghafar. (2003). Reka Bentuk Tinjauan Soal Selidik Pendidikan. Skudai: Universiti Teknologi Malaysia.

Muhammad Amin, Rahmat ullah Shah, Muhammad Ayaz, \& Malik Amer Atta. (2013). Teachers' Job Performance at Secondary Level in Khyber Pakhyunkhwa, Pakistan. Gomal University Journal of Research, 29(2), 100-104.

Nadiah Bani Amin, Amizawati Mohd Amir, \& Siti Farahhani Ismail. (2019). "Key Performance Indicators Tugas, Ganjaran dan Prestasi Kerja Guru Sekolah Kerajaan." JuPiDi: Jurnal Kepimpinan Pendidikan, 6(4), 38-60.

Noel, T. W. (2009). The Impact of Knowledge Resources on New Venture Performance. Journal of Small Business Mnagement, 47(1), 1-22.

Noriati A. Rashid, Boon Pong Ying \& Wong Kiet Wah. (2010). Asas Kepimpinan dan Perkembangan Profesional Guru. Shah Alam : Oxford Fajar.

Norsimah Dasan \& Mohd Mahadzir Rahimi Mohamed Nawi. 2020. Hubungan Efikasi Kendiri Guru Dengan Prestasi Kerja Dalam Kalangan Guru Maktab Rendah Sains Mara (MRSM). Journal of Social Sciences and Humanities, 7(4), 173-187.

Osagie, C. I., \& Akinlosotu, N. T. (2017). Causal Relationship between Teachers' Job Performance and Students' Academic Achievement in Secondary Schools in Nigeria. African Research Review, 11(4), 45-54.

Rahimah Jamalaluddin, Rosini Abu, Abdullah Mat Rashid \& Habsah Ismail. (2014). Tahap efikasi Guru dalam Melaksanakan Pengajaran Kekeluargaan. Sains Humanika, 2(4), 163-168.

Rohman Hidayatul Attoriq (2020). Pengaruh Efikasi Diri Terhadap Kinerja Pns Guru Sman Wilayah Ii Jakarta Pusat. Mozaic: Islam Nusantara, 6(2), 127-136.

Senemoglu, N \& Demirel, M. (2009). Elementary School Teacher's Efficacy Belief: A Turkish Case. Humanity and Social Journal, 4(2), 167-171. 
Shafinaz A. Maulod, Chua Yan Piaw, Hussein Ahmad, Leong Mei Wei \& Shahrin Alias. (2017). Kecerdasan Emosi Pengetua dan Hubungannya dengan Efikasi Kendiri Guru Sekolah Menengah. JuPiDi: Jurnal Kepimpinan Pendidikan, 3(3), 54-75.

Song, J. H., Chai, D. S., Kim, J., \& Bae, S. H. (2018). Job Performance In The Learning Organization: The Mediating Impacts of Self-Efficacy And Work Engagement. Performance Improvement Quarterly, 30(4), 249-271.

Syed Kamarzuaman Syed Ali, Mohd Zaki Che Hassan \& Julismah Jani. (2014). Efikasi Kendiri Guru Pendidikan Jasmani Terhadap Pelaksanaan Pengajaran Mata Pelajaran Pendidikan Jasmani. JuKu: Jurnal Kurikulum \& Pengajaran Asia Pasifik, 2(3), 43-51.

Syed Ismail Syed Mustapa \& Ahmad Subki Miskon. (2010). Guru Dan Cabaran Semasa. Selangor Darul Ehsan: Penerbitan Multimedia Sdn. Bhd.

Teng Lung Kiu. (2006). Pengaruh Faktor Terpilih Terhadap Efikasi Kendiri Guru Sekolah Menengah di Negeri Sarawak. PhD Thesis. Universiti Putra Malaysia.

Tschannen-Moran, M., Hoy, A.W. \& Hoy, W.K. (1998). Teacher Efficacy: Its Meaning and Measure. Review of Educational Research, 68(2), 202-248.

Wan Mohd. Zahid Mohd Nordin. (1993). Pengisian Wawasan Pendidikan. Kertas Kerja dalam Persidangan Pendidikan Nasional. Institut Aminuddin Baki, Genting, 8-11 April.

Wan Mohd. Zahid Mohd Nordin. (1994). Wawasan Pendidikan Agenda Pengisian. Kuala Lumpur: Cahaya Pantai Publishing (M) Sdn. Bhd.

Woolfolk-Hoy, A. (2000). Changes in Teacher Efficacy During the Early Years of Teaching. Paper Presented at The Annual Meeting of The American Educational Research Association, New Orleans, LA. Session 43:22, Qualitative and Quantitative Approaches to Examining Efficacy in Teaching and Learning.

Yusof Jasmin @ Joseph Gimbad. 2007. Pengaruh Kepemimpinan Pengajaran Guru Besar Dan Pelaksanaan Tugas Guru Ke Atas Amalan Pengajaran Berkesan Di Sekolah Kurang Murid Negeri Sabah. Tesis Doktor Falsafah: Universiti Malaysia Sabah.

Zuhaili Mohd Arshad \& Ramlee Mustapha (2017). Hubungan Antara Beban Tugas dengan Efikasi Diri dan Kepuasan Kerja Pensyarah di Kolej Vokasional. Sains Humanika, 9(1-5). 